\title{
EDITORIAL
}

\section{COVID-19 pandemic: The value of antibody testing for imaging facilities}

Anirudh Kohli

Breach Candy Hospital and Research Centre, 60 Bhulabhai Desai Road, Mumbai, Maharashtra, India. E-mail: dranirudhkohli@gmail.com

The human body responds to viral infections by producing antibodies. Severe acute respiratory syndrome coronavirus 2 (SARS COV-2) is no different as it stimulates a rapid antibody response in symptomatic and asymptomatic infected individuals. Immunoglobulin M (IgM) titres indicating a recent infection start to rise from day 5 and immunoglobulin $G(\operatorname{IgG})$ indicating an older infection start to rise after 14 days. The IgG levels tend to rise over the next few months. The duration of antibodies that persist is unknown as SARS COV-2 is a fairly new infection. ${ }^{[1,2]}$ Persistence for at least 60 days is documented ${ }^{[3]}$ with personal communications indicating the persistence of antibodies at even 4 months. Antibodies from the previous coronavirus SARS COV 1 persisted for between 2 and 6 years. The level of antibodies can be measured in serum with quantitive assays.

There are two main categories of IgG antibodies, binding and neutralising. Binding antibodies bind to the nucleocapsid of the SARS COV-2 virus. These bind to the pathogen, however, not necessarily render the pathogen non-infectious. The main utility is to demonstrate the extent of prevalence of the disease in the community. Neutralising antibodies are antibodies to the spike protein which binds to the receptor-binding domain of the spike rendering the pathogen noninfectious as it is unable to bind with the angiotensin-converting enzyme (ACE) receptor, thus the virus cannot enter the cell. These are known as neutralising antibodies. Similar principle is encountered in vaccine development.

The sensitivity of both assays is very high at $100 \%$ with a specificity of $99.8 \%{ }^{[3]}$

Healthcare workers are particularly vulnerable to contract SARS COV-2, especially at the workplace. They also do not have the luxury of work from home thus need to commute to their healthcare facility often by public transport, being exposed to community mobility. Further, they may reside in hot spots/containment zones.

With the pandemic having raged for 6 months, there has been extensive mild symptomatic and asymptomatic infection, especially in the lower socio-economic, densely populated areas as well as individuals exposed to community mobility.

A serosurvey amongst healthcare workers is useful for two important reasons to assess infection control practises and safety.

A high percentage of staff with antibodies may be an indicator of inadequate infection control practises. Individuals with high antibody titres will need to be interrogated regarding the source of exposure to SARS COV-2. This may be at residence from other family members or neighbours, a community such as shopping/recreational areas, due to community mobility such as public transport or at the healthcare facility. If it is deemed that exposure occurred at the healthcare facility it is important to re-evaluate all infection control practises as well as educate staff on infection control routines. The practises of safe distancing for relatives, patients and staff need to be evaluated. Status of contaminated, buffer and green zones to see if there is any contamination in the green zones. Evaluation of appropriate donning doffing personal protective equipment (PPE) techniques and appropriate discard off PPE. Surface decontamination practises such as X-ray detectors, sonography probes, all machines and departmental surfaces. Shift to electronic delivery of images and reports, to remove as much of fomites transmission as possible. An important zone to be monitored is the tea and lunchroom where individuals are de-masked. This is a common area for infection to spread if staff crowds these rooms, gossips and spends time in a small closed space without their masks on.

A high percentage of staff with neutralising antibodies lends safety to co-workers and patients. If front-line staff - resident doctors, $X$-ray technicians, nurses and ward boys who come in contact with patients have neutralising antibodies it is a boon. They can be deployed to the frontline safely. During the pandemic most imaging facilities have seen drops in volume $70-90 \%$, patients are staying away from imaging facilities. ${ }^{[4]}$ Safe front-line workers with neutralising antibodies will lend confidence to these individuals to return to imaging facilities and thus help in bringing normalcy back to life much earlier than expected. 
It is also useful to obtain antibody testing of patients before procedures as this lends an aura of confidence to the interventionist and staff. Lack of antibodies would imply the patient needs to be treated as a COVID positive. Some feel all should be treated as COVID positive with universal precautions. This is true, however, a simple antibody test can save excessive expenditure on PPE and other measures.

It is ideal to retest for antibodies every 4 weeks as it is still unknown how long antibody titres last.

Antibody testing is a great boon for imaging departments as the cost is low 500 INR, turn-around time is quick $1 \mathrm{~h}$ and the benefits of a positive test for neutralising antibodies is immense.

\section{References}

1. Wu F, Wang A, Liu M, Wang Q, Chen J, Xia S, et al. Neutralizing antibody responses to SARS-CoV-2 in a COVID-19 recovered patient cohort and their implications. medRxiv 2020; published online April 20. doi: 10.1101/2020.03.30.20047365 (preprint).

2. Liu W, Liu L, Kou G, Zheng Y, Ding Y, Ni W, et al. Evaluation of nucleocapsid and spike protein-based enzyme-linked immunosorbent assays for detecting antibodies against SARS-CoV-2. J Clin Microbiol 2020;58. doi: 10.1128/JCM.00461-20.

3. Siddiqui A, Naushin S, Pradhan S, Misra A, Tyagi A, Loomba M, et al. SARS-CoV-2 antibody seroprevalence and stability in a tertiary care hospital-setting. medRxiv. doi: 10.1101/2020.09.02.20186486.

4. Naidich JJ, Boltyenkov A, Wang JJ, Chusid J, Hughes D, Sanelli PC. Impact of the Coronavirus disease 2019 (COVID-19) pandemic on imaging case volumes. J Am Coll Radiol 2020;17:865-72. doi: 10.1016/j.jacr.2020.05.004.

This is an open access journal, and articles are distributed under the terms of the Creative Commons Attribution-NonCommercial-ShareAlike 4.0 License, which allows others to remix, tweak, and build upon the work non-commercially, as long as appropriate credit is given and the new creations are licensed under the identical terms.

\begin{tabular}{|l|l|}
\hline \multicolumn{2}{|c|}{ Access this article online } \\
\hline Quick Response Code: & \\
\hline & Website: \\
\hline & www.jri.org \\
& \\
\hline
\end{tabular}

Cite this article as: Kohli A. COVID-19 pandemic: The value of antibody testing for imaging facilities. Indian J Radiol Imaging 2020;30:251-2.

Received: 08-Oct-2020 Revision: 08-Oct-2020

Accepted: 08-Oct-2020 